\title{
THE COLORIMETRIC DETERMINATION OF LIPASE AND ESTERASE IN HUMAN SERUM ${ }^{2}$
}

\author{
By ARNOLD M. SELIGMAN AND MARVIN M. NACHLAS 2 \\ (From the Kirstein Laboratory for Surgical Research, Beth Israel Hospital, Boston, and the \\ Department of Surgery, Harvard Medical School, Boston)
}

(Received for publication July 18, 1949)

A wide variety of esters have been utilized as substrates for the measurement of the esterolytic activity of serum. From these studies it has become increasingly clear that there are at least two distinct esterolytic enzymes, esterase and lipase. Esterase is abundant in liver, kidney, blood serum, and pancreas, preferentially hydrolyzes esters of short chain fatty acids, and is inhibited partially by sodium taurocholate (1-3). Lipase is abundant almost exclusively in pancreas, preferentially hydrolyzes esters of long chain fatty acids and its activity is accelerated by sodium taurocholate (1-3). Although the measurement of serum esterase has not been demonstrated to be of clinical value, the measurement of serum lipase has been found to be useful in the diagnosis of pancreatic disease $(4,5)$.

The three methods described for the measurement of serum lipase use, as substrates respectively: tributyrin (6); "Tween," a polyglycol ester of stearic acid (7); or olive oil (8). Because "Tween" and tributyrin are extensively hydrolyzed by esterase as well as by lipase, the most widely used method is that of Cherry and Crandall, which titrates with $\mathrm{N} / 20$ sodium hydroxide the fatty acids liberated when $1 \mathrm{cc}$. of serum is incubated for 24 hours with an olive oil emulsion. Although this method may be reliable in experienced hands, technical difficulties, such as the unsatisfactory end-point in the presence of protein, instability of the oil emulsion, and occasional spontaneous hydrolysis of the oil, limit its usefulness as a routine laboratory procedure.

Following the development of a histochemical method for demonstrating esterase (9) with the substrate beta naphthyl acetate, long chain fatty

\footnotetext{
1 This investigation was aided by a research grant from the National Cancer Institute, National Institutes of Health, Public Health Service, (in part) by a grant from the Massachusetts Division of the American Cancer Society, and (in part) by an institutional grant to Harvard University from the American Cancer Society.

2 Research fellow of the National Cancer Institute.
}

acid esters of beta naphthol were prepared (3) and their hydrolysis by the esterolytic enzymes of several tissues in several species was explored, together with the effects of various known inhibitors and accelerators of esterase and lipase activity (3). It was then found that the lipase content of dog serum could be measured accurately by these newer substrates. Increases in serum lipase after injection of mecholyl and eserine could also be readily demonstrated in dogs, particularly when lipase activity was stimulated by sodium taurocholate (10). The latter effect was so constant and striking that the substrate, beta naphthyl laurate (I) which is hydrolyzed by both esterase and lipase, can be used to measure each of the enzymes accurately by a convenient colorimetric method. The beta naphthol (II), produced by enzymatic hydrolysis, is converted to a purple azo dye (IV) by the coupling of two molecules with tetrazotized diorthoanisidine (III). This pigment is then extracted with ethyl acetate and the optical density measured colorimetrically. A description of the method and its use in normal and abnormal sera follows.

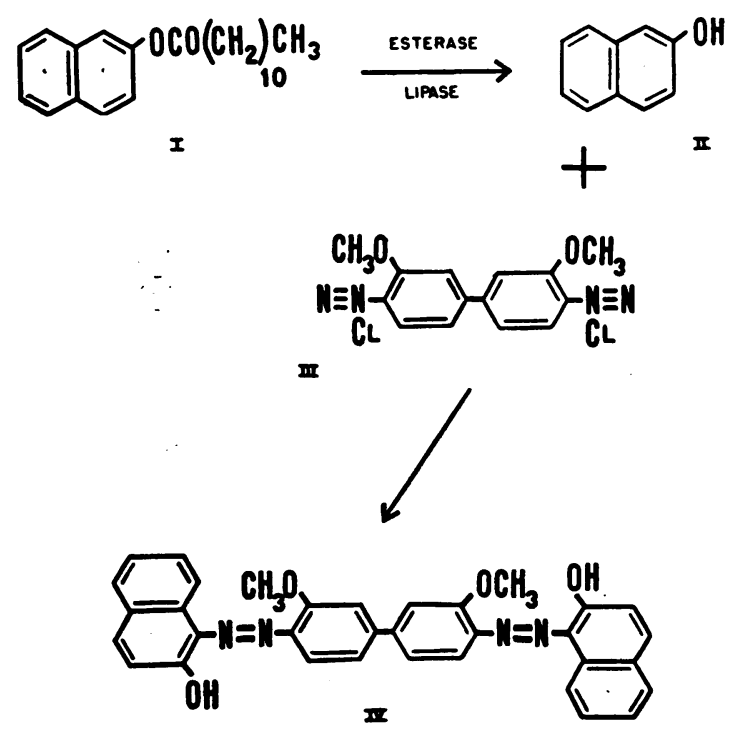




\section{METHOD}

\section{A. Reagents 8}

1. Beta naphthyl laurate (I). The synthesis of this substrate is described elsewhere (3). It was found convenient to keep a tightly stoppered stock solution of 200 mgms. per $100 \mathrm{cc}$. of acetone in the refrigerator.

2. Tetrazotized diorthoanisidine (III). 4 The powder was dissolved in cool water immediately before use.

3. Sodium taurocholate (Eastman technical grade). A solution $\left(8 \times 10^{-2} \mathrm{M}\right)$ was prepared by dissolving 890 mgms. in $100 \mathrm{cc}$. of water and stored at $4^{\circ} \mathrm{C}$. for as long as a month.

4. $0.1 M$ Veronal buffer, $\mathrm{pH} 7.4$, was prepared according to Michaelis (11), by mixing $58 \mathrm{cc}$. of a solution containing $10.3 \mathrm{gms}$. of sodium diethyl-barbiturate in $500 \mathrm{cc}$. of water, with $42 \mathrm{cc}$. of $0.1 \mathrm{M}$ hydrochloric acid. Stored at $4^{\circ} \mathrm{C}$., it could be used for a month. If stored longer or at room temperature, non-enzymatic hydrolysis of the substrate in control tubes was observed.

5. Trichloracetic acid solution $(40 \%)$.

6. Ethyl acetate.

\section{B. Technique}

Clotted blood (5 cc.) is centrifuged for 10-15 minutes at 2000 r.p.m. Determinations are made in duplicates. With a 0.2 cc. pipette, serum is transferred into each of four test tubes, two of which contain $1 \mathrm{cc}$. of water each, and two of which contain $1 \mathrm{cc}$. of the sodium taurocholate solution. A fifth tube containing $2 \mathrm{cc}$. of water is used as a control. The substrate solution is prepared by adding $5 \mathrm{cc}$. of the stock solution of naphthyl laurate in acetone through a submerged pipette into an agitated aqueous mixture composed of $10 \mathrm{cc}$. of veronal buffer and $35 \mathrm{cc}$. of water. A cloudy solution is produced which contains $0.2 \mathrm{mgm}$. per cc. This colloidal suspension ( 5 cc.) is added to each of the five test tubes above, and incubation at $37.5^{\circ} \mathrm{C}$. is allowed to proceed for five hours. To each test tube is then added $1 \mathrm{cc}$. of a cool solution of tetrazotized diorthoanisidine, prepared immediately before use from $40 \mathrm{mgms}$. of the powder in $10 \mathrm{cc}$. water. This is followed in two minutes by 1 cc. of $40 \%$ trichloracetic acid solution. The purple pigment is then extracted by vigorously shaking each tube with $10 \mathrm{cc}$. ethyl acetate. The tubes are centrifuged for five minutes, and $5 \mathrm{cc}$. of each clear red organic layer are transferred with a pipette to a colorimeter tube. The color density is then determined with a photoelectric colorimeter (Klett) through a $540 \mathrm{~m} \mu$ filter. The visible absorption spectrum of the azo dye (IV) is shown in Figure 1.

${ }^{3}$ All reagents for this method may now be purchased from Monomer-Polymer, Inc., 3430 West Henderson St., Chicago 18, Ill.

4 Available commercially in powder form as "Naphthanil Diazo Blue B," containing 20\% tetrazotized diorthoanisidine, $5 \%$ zinc chloride and $20 \%$ aluminum sulfate. Provided through the courtesy of Dr. E. R. Laughlin, du Pont de Nemours \& Co., Boston. See footnote 3.

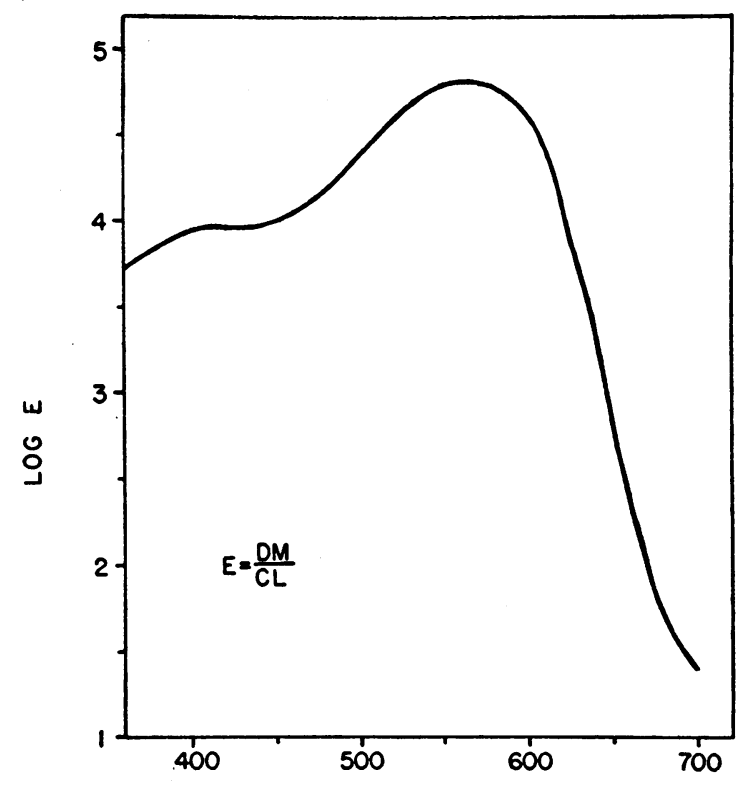

WAVELENGTH IN MILLIMICRONS

Fig. 1. Visible Absorption Spectrum of the Azo Dye (IV) Produced by Coupling of 2 Moles of Beta Naphthol (II) with Tetrazotized Diorthoanisidine (III)

$\mathrm{E}$ is the molecular extinction coefficient; $\mathrm{D}$, optical density; M, molecular weight (IV); C, concentration of the azo dye in chloroform (gms. per liter); L, cell length $(\mathrm{cm}$.$) . We are indebted to Dr. Elkan R. Blout,$ Research Laboratory of Polaroid Corporation, Cambridge, for these measurements.

With normal serum, the color density of the tubes without taurocholate was greater than in those with this reagent, which partially inhibits esterase. The greater values obtained in the absence of taurocholate are a measure of non-specific esterase 5 activity (Table I). However, when lipase is present in the serum, the color density of the tubes containing taurocholate is greater than that of the tubes without it, because of stimulation of lipase activity by this substance. The difference in the color density between the tubes is related to the amount of lipase irrespective of the esterase content (Figure 2). Color density is converted to milligrams of naphthol from a calibration curve (Figure 3), prepared by substituting various quantities of beta naphthol for the substrate solution and carrying out the procedure outlined above.

One unit of lipase is herein defined as that quantity of enzyme, which in the presence of sodium taurocholate is able to liberate $0.01 \mathrm{mgm}$. of naphthol from beta naphthyl laurate in five hours at $37.5^{\circ} \mathrm{C}$. in excess of that

${ }^{5} \mathrm{~A}$ more rapid estimate of esterase activity (20 minutes) may be obtained with the substrate, beta naphthyl acetate (10). 
TABLE I

Esterolytic activity of 0.2 cc. normal human sera upon beta naphthyl laurate with and without sodium taurocholate

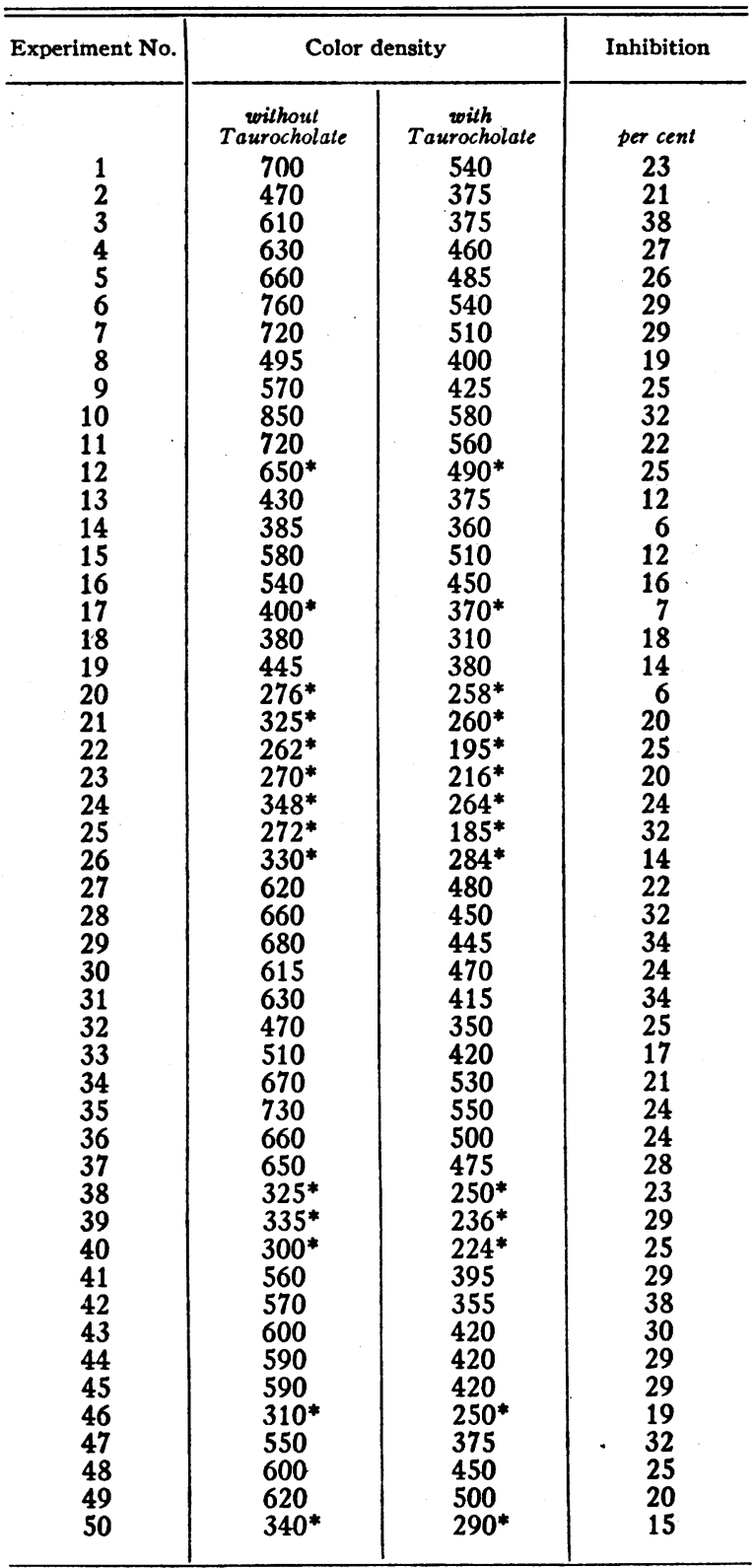

* Ethyl acetate extract was diluted 1:1 before determination of color density.

liberated by the esterase present in the same quantity of serum.

\section{RESULTS}

Normal serum from 50 humans was studied. Esterase activity in milligrams of naphthol varied from 0.03 to 0.1 per $0.2 \mathrm{cc}$. of serum. Inhibition of esterase by taurocholate ranged from $6 \%$ to

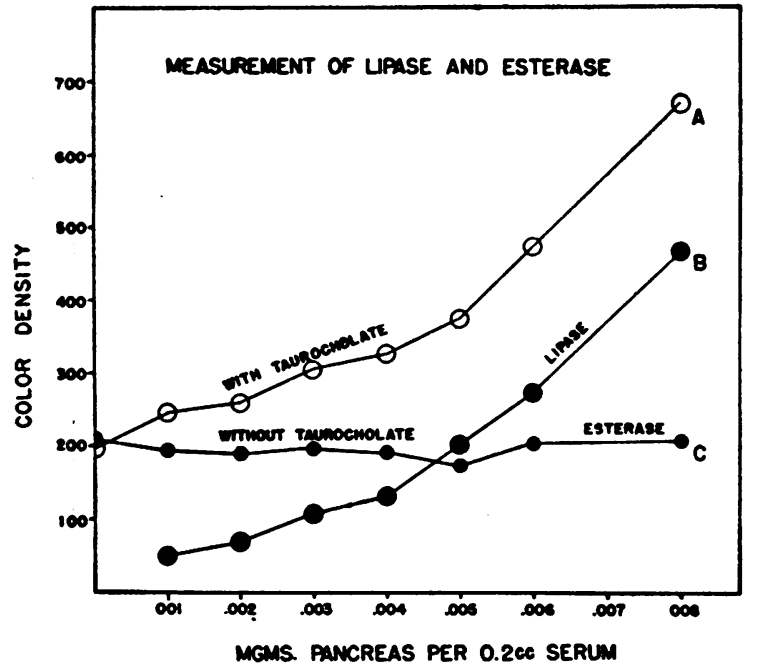

Fig. 2

Homogenized human pancreas was added in fixed increments to $0.2 \mathrm{cc}$. of normal serum. These solutions were incubated in duplicate, with taurocholate (curve A) and without taurocholate (curve C) for five hours at $37.5^{\circ} \mathrm{C}$. The azo dye, which was produced by coupling, was extracted with ethyl acetate for measurement of the color density. Curve $\mathrm{B}$ was obtained by the difference of curves $\mathrm{A}$ and $\mathrm{C}$. Curve $\mathrm{C}$ measures esterase activity and was not influenced by the small amount of added pancreas. Curve A measures both esterase and lipase activity. Curve B denotes lipase activity exclusively.

$38 \%$. No acceleration due to taurocholate was present. Hence no measurable quantity of lipase was found in the serum by this method. The color density of the tubes with and without taurocholate is given in Table I.

The small amount of hydrolysis of olive oil obtained by the method of Cherry and Crandall (8) in normal serum, attributed to traces of lipase is, we believe, due to esterase. In contrast to man, lipase was demonstrated in the serum of normal dogs by our method (10).

\section{Effect of varying lipase concentration}

In order to determine whether the increased hydrolysis of naphthyl laurate produced by taurocholate is directly related to the concentration of lipase, homogenized pancreatic tissue (human) in graded amounts was added to normal serum. Each $0.2 \mathrm{cc}$. of serum was made to contain from 0.001-0.008 mgm. (wet weight) of pancreas. Five experiments were performed. The results of one experiment are shown in Figure 2. Without 


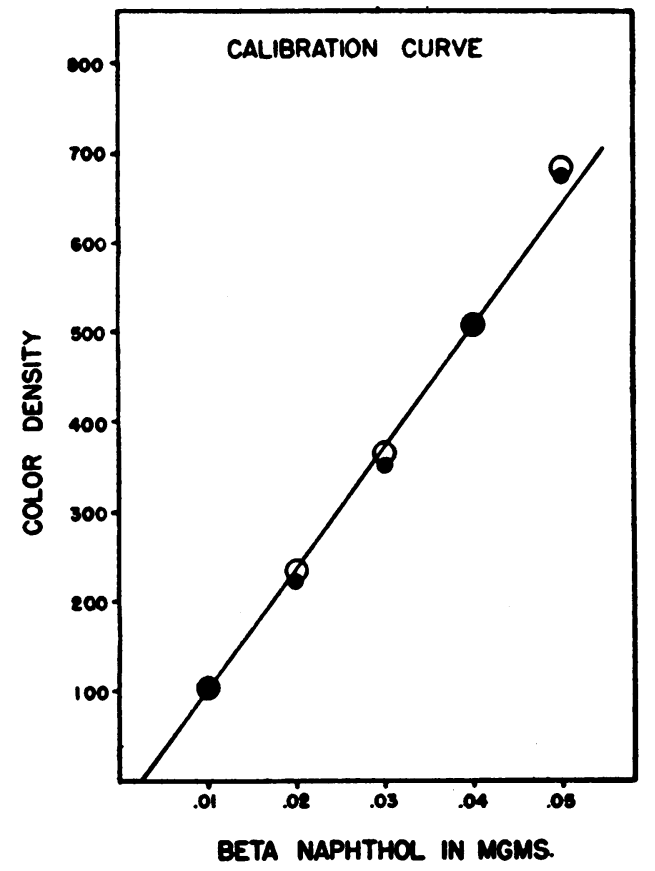

Fig. 3

Fixed increments of beta naphthol were added to 0.2 cc. of normal serum and the procedure carried out as with the test serum. The hollow circles indicate experiments with twice the quantity of naphthol, and in which the ethyl acetate extract was diluted 1:1 before measuring the color density. The values plotted are averages of four experiments.

taurocholate, only esterase could be demonstrated with these quantities of pancreas. With taurocholate, the lipase in as little as $1 \mu \mathrm{g}$. of pancreas could be demonstrated. As much as $8 \mu \mathrm{g}$. resulted in an optical density near the upper limit of the colorimeter. The lipase curve (Figure 2, curve B) was almost linear between concentrations of pancreas from 0.001 to $0.005 \mathrm{mgm}$. per $0.2 \mathrm{cc}$. serum. The method was capable of detecting regularly the lipase activity of as little as $0.01 \mathrm{mgm}$. of pancreas per cc. of serum (2.5 to 5.0 units of lipase per cc. of serum).

\section{Comparison of colorimetric with titrimetric method}

The lipase activity of normal serum fortified with pancreas at various concentrations as measured by the colorimetric method was compared with the results on the same preparations from two other laboratories ${ }^{B}$ using the olive oil method

\footnotetext{
6 We wish to acknowledge our indebtedness to Miss Margaret Rourke and Miss Alice Riley, Clinical Labora-
}

$(8,12)$. The results in cc. of $N / 20$ sodium hydroxide and in lipase units are given in Table II. Three of these determinations with the titrimetric method fell within the normal range, three others were slightly elevated, and two were substantially elevated. In contrast, the colorimetric method not only detected increased lipase in every specimen, but demonstrated that the lipase concentration paralleled the concentration of added pancreas. Moreover, while the titrimetric method required 24 hours of incubation, the colorimetric method required only five hours.

\section{Comparison of sensitivity of lipase and amylase determinations}

A markedly elevated serum amylase is considered indicative of an excess of pancreatic enzymes in the blood. In order to compare the sensitivity of the two methods in detecting pancreatic enzymes in serum, small amounts of homogenized pancreas (0.02-0.06 mgm. per cc.) were added

TABLE II

Comparison of hydrolytic activity of lipase upon olive oil and naphthyl laurate

\begin{tabular}{|c|c|c|c|c|c|}
\hline \multirow[b]{2}{*}{$\begin{array}{c}\text { Experi- } \\
\text { ment }\end{array}$} & \multirow{2}{*}{$\begin{array}{c}\text { Pancreas* } \\
\text { added } \\
\text { per } \\
\text { cc. of } \\
\text { serum }\end{array}$} & \multicolumn{2}{|c|}{ Olive oil } & \multicolumn{2}{|c|}{ Naphthyl laurate } \\
\hline & & $\begin{array}{c}\text { Lab. At } \\
\text { cc. N/20, } \\
\text { NaOH } \\
\text { per cc. } \\
\text { serum }\end{array}$ & $\begin{array}{c}\text { Lab. Bł } \\
\text { cc. N/20, } \\
\text { NaOH } \\
\text { per cc. } \\
\text { serum }\end{array}$ & $\begin{array}{l}\text { Naphthol } \\
\text { micromoles } \\
\text { per } 0.2 \mathrm{cc} \text {. } \\
\text { serum }\end{array}$ & $\begin{array}{c}\text { Lipase } \\
\text { units per } \\
0.2 \mathrm{cc} \text {. } \\
\text { serum }\end{array}$ \\
\hline $\mathbf{A}$ & $\begin{array}{l}\text { mgms. } \\
0 \\
0.02 \\
0.04\end{array}$ & Z & $\begin{array}{l}0.55 \\
1.10 \\
1.92\end{array}$ & $\begin{array}{l}0 \\
0.07 \\
0.28\end{array}$ & $\begin{array}{l}0 \\
1.0 \\
3.7\end{array}$ \\
\hline B & $\begin{array}{l}0.01 \\
0.02 \\
0.04\end{array}$ & $\begin{array}{l}1.22 \\
1.37 \\
1.72\end{array}$ & $\begin{array}{l}0.87 \\
0.95 \\
0.70\end{array}$ & $\begin{array}{l}0.04 \\
0.13 \\
0.31\end{array}$ & $\begin{array}{l}0.6 \\
1.8 \\
4.4\end{array}$ \\
\hline
\end{tabular}

* Homogenized human pancreas (wet weight) added to normal human serum.

† Clinical laboratory, Massachusetts General Hospital, method of Cherry and Crandall (8) in which normal value for $1 \mathrm{cc}$. of serum incubated for 24 hours is up to $2 \mathrm{cc}$.

$\ddagger$ Clinical laboratory, New England Medical Center. Modified method of Cherry and Crandall (12) in which the upper limit of normal is 0.5-1.0 cc.

Lipase unit is defined as that quantity of enzyme which. in the presence of sodium taurocholate, is able to liberate $0.01 \mathrm{mgm}$. of naphthol from beta naphthyl laurate in five hours at $37.5^{\circ} \mathrm{C}$. in excess of that liberated by the esterase present in the same quantity of serum.

tory, Massachusetts General Hospital, and Mr. Joseph Benotti and Miss Mary Powers, New England Medical Center, for their generosity and cooperation in performing for us the determinations of lipase by the titrimetric method. 
TABLE III

Comparison of amylase and lipase activities of the same fortified serum

\begin{tabular}{c|c|c|c}
\hline Experiment & $\begin{array}{c}\text { Pancreas* added } \\
\text { per cc. of serum }\end{array}$ & $\begin{array}{c}\text { Amylaset units } \\
\text { per cc. serum }\end{array}$ & $\begin{array}{c}\text { Lipaset units } \\
\text { per cc. } \\
\text { serum }\end{array}$ \\
\cline { 2 - 3 } A & $\begin{array}{c}\text { mgms. } \\
0.02\end{array}$ & 47 & 2.5 \\
\hline B & 0.04 & 52 & 20 \\
\hline & 0.02 & 79 & 17 \\
& 0.02 & 76 & 17 \\
C & 0.04 & 75 & 39 \\
\hline & 0.02 & 63 & 19 \\
\hline
\end{tabular}

* Homogenized human pancreas (wet weight) added to normal human serum.

† Method of Somogyi (13). Normal up to 100 units.

$\mp$ Lipase unit is defined as that quantity of enzyme which, in the presence of sodium taurocholate, is able to liberate $0.01 \mathrm{mgm}$. of naphthol from beta napthyl laurate in five hours at $37.5^{\circ} \mathrm{C}$. in excess of that liberated by the esterase present in the same quantity of serum.

to normal serum. The results of lipase and amylase $^{7}$ determinations are given in Table III. Although the lipase content of serum was demonstrated and correlated with the concentration of added pancreas, the amylase values were all within normal limits. This is surprising since the lipase content in some instances was near the upper limit of the method. Around $1 \mathrm{mgm}$. of pancreas was required to give significantly elevated amylase values.

\section{Abnormal human serum}

In the course of this investigation, three patients presented themselves for study. Two of these had a past history of pancreatitis, and were admitted acutely ill with the symptoms and signs leading to a diagnosis of recurrent acute pancreatitis. In one (S. S., No. BIH-M3479) the serum amylase was 1400 units and the lipase was 1.0 unit per $0.2 \mathrm{cc}$. serum. In the other (S. B., MGH No. 647240) two serum amylase determinations were markedly elevated, and the serum lipase (colorimetric) was 1.4 units per $0.2 \mathrm{cc}$. serum.

A third patient (L. A., No. BIH-M3906) had inoperable carcinoma of the pancreas, diagnosed

? We wish to acknowledge our indebtedness to Miss Alice I. McCarthy, Clinical Laboratory, Beth Israel Hospital, for her generosity and cooperation in performing the amylase determinations. The method used was that of Somogyi (13). at operation five months previously. His serum $(0.2 \mathrm{cc}$.) contained 0.5 units of lipase.

\section{DISCUSSION}

The determination of serum lipase has been shown to be of value in the diagnosis of pancreatic disease $(4,5)$. Reasons for the lack of general clinical use are probably found not only in the technical difficulties of the methods, but also in the lack of specificity for lipase particularly with substrates other than olive oil.

Although it has been recognized that liver, kidney, pancreas, and serum possess an esterolytic enzyme efficient in the hydrolysis of esters containing short chain fatty acids, and that pancreas alone readily hydrolyzed the long chain fatty acid esters, the classification of enzymes on this basis alone was subject to doubt, because of overlapping of enzymatic activity. It seemed likely, therefore, that the use of any ester as a substrate would theoretically measure both esterase and lipase if present together. For example, since human serum is extremely rich in esterase, the question arose as to how much of the observed hydrolysis of naphthyl palmitate-stearate (10) and of laurate was due to esterase. The difficulty was circumvented by the use of an observation described long ago (1); i.e., that taurocholate stimulated lipase activity and depressed esterase activity. This not only provided a degree of specificity not possessed by other methods but also increased the sensitivity of the method. It was possible to show by the absence of stimulation by taurocholate that naphthyl palmitate-stearate (30 unpublished cases) and to a greater degree, naphthyl laurate, were hydrolyzed by non-specific esterase in normal human serum. These considerations probably explain the discrepancy in reported lipase content of normal human serum by the titrimetric method with olive oil as substrate and the absence of lipase by the colorimetric method. The lipase stimulating action of calcium oleate has been used similarly to improve the specificity of the determination of serum lipase with the substrate, tributyrin (14). With this method human serum did not contain lipase.

Several interesting observations were noted in the brief clinical experience with this method. In addition to the three cases reported above, seven others were found not to have lipase in their serum, 
although they were reported to have elevated levels of serum amylase, urinary amylase, or serum lipase by. the titrimetric method. Two of the three patients shown to have lipase in the serum by' the colorimetric method, showed very high levels of amylase activity, out of proportion to the lipase levels. This lack of correlation between the two enzyme levels is consistent with the experiments in which pancreas was added to serum. Experiments are in progress to clarify the apparent lack of correlation between the serum amylase levels and the serum lipase content as determined by the titrimetric and colorimetric methods.

\section{SUMMARY}

1. A new method for the determination of serum lipase is presented. This colorimetric method is specific, sensitive, and convenient to perform.

2. The colorimetric method for lipase is compared with the sensitivity of the titrimetric method.

3. A new method for the determination of serum esterase is also included.

4. Results with 50 normal sera and three abnormal sera are given.

5. The serum amylase levels were not found to correlate with the levels of serum lipase or with the lipase content of pancreatic tissue when added to serum.

\section{ACKNOWLEDGMENTS}

Asknowledgment is due Miss Marie Mollomo for technical assistance, and to Mrs. Dorothea Frazer, for collecting the normal serum.

\section{BIBLIOGRAPHY}

1. Willstätter, R., and Memmen, F., Uber die Wirkung des Pankreaslipase auf verschiedene Substrate. Ztschr. f. physiol. Chem., 1924, 133, 229.
2. Gomori, G., Histochemical differentiation between esterases. Proc. Soc. Exper. Biol. \& Med., 1948, 67, 4.

3. Nachlas, M. M., and Seligman, A. M., Evidence for the specificity of esterase and lipase by the use of three chromogenic substrates. J. Biol. Chem., 1949, 181, 343.

4. Comfort, M. W., and Osterberg, A. E., Serum amylase and serum lipase in the diagnosis of disease of the pancreas. M. Clin. North America, 1940, 24, 1137.

5. Johnson, T. A., and Bockus, H. L., Diagnostic significance of determinations of serum lipase. Arch. Int. Med., 1940, 66, 62.

6. Goldstein, N. P., Epstein, J. H., and Roe, J. H., Studies of pancreatic function. IV. A simplified method for the determination of serum lipase, using aqueous tributyrin as substrate, with one hundred normal values by this method. J. Lab. \& Clin. Med., 1948, 33, 1047.

7. Archibald, R. M., Determination of lipase activity. J. Biol. Chem., 1946, 165, 443.

8. Cherry, I. S., and Crandall, L. A., Jr., The specificity of pancreatic lipase: its appearance in the blood after pancreatic injury. Am. J. Physiol., 1931, 100, 266.

9. Nachlas, M. M., and Seligman, A. M., The histochemical demonstration of esterase. J. Nat. Cancer Inst., 1949, 9, 415.

10. Seligman, A. M., Nachlas, M. M., and Mollomo, M. C., The colorimetric determination of lipase and esterase in dog's serum. Am. J. Physiol., 1949, $159,337$.

11. Michaelis, L., Diethylbarbiturate buffer. J. Biol. Chem., 1930, 87, 33.

12. Nothman, M. M., Pratt, T. D., and Benotti, J., The effect of ligation of pancreatic ducts and of pancreatectomy after duct ligation on the serum lipase of the dog. J. Lab. \& Clin. Med., 1948, 33, 833.

13. Somogyi, M., Micromethod for the estimation of diastase. J. Biol. Chem., 1938, 125, 399.

14. Lagerlöf, H., Normal esterases and pancreatic lipase in the blood. Acta med. Scandinav., 1945, 120, 407. 